\title{
Koordinasi Empat Simpang Bersinyal Untuk Kelancaran Arus Lalu Lintas Di Kota Banjarmasin
}

\author{
Ocky S Pribadi, Raja Fajri, Robert Simanjuntak \\ Politeknik Transportasi Darat Bali \\ Email: Ockysp71@gmail.com
}

\begin{abstract}
Abstrak
Jarak antar simpang yang pendek menyebabkan kendaraan mengalami tundaan setiap melewati persimpangan. Penelitian bertujuan untuk memberikan kelancaran arus lalu lintas pada ruas jalan yang menghubungkan bagian CBD Kota Banjarmasin. perencanaan koordinasi waktu sinyal diharapkan dapat mengurangi tundaan pada persimpangan dan meningkatkan kecepatan kendaraan. Perhitungan kinerja eksisting persimpangan dilakukan dengan menggunakan PKJI 2014, dan Metode Webster. Koordinasi sinyal membutuhkan waktu siklus yang sama untuk keempat simpang yang didapatkan dari hasil optimasi persimpangan yang paling optimal sehingga didapatkan waktu siklus yaitu 116 detik. Analisis koordinasi sinyal dengan memperhatikan tingkat penyebaran pleton dan jarak antar simpang serta kecepatan kendaraan menggunakan teori offset dan bandwith sehingga pleton semaksimal mungkin mendapatkan sinyal hijau yang berkelanjutan. Hasil penelitian menunjukkan peningkatan kinerja persimpangan setelah dikoordinasikan yaitu penurunan nilai derajat kejenuhan rata-rata sebesar $10,81 \%$, penurunan panjang antrian rata-rata sebesar $7,61 \%$, dan penurunan tundaan rata-rata sebesar $2,69 \%$.
\end{abstract}

Kata Kunci: Tundaan, Koordinasi Sinyal, Peningkatan kinerja.

\begin{abstract}
The short distance between intersections causes vehicles to experience delays every time they pass through the intersection. This study aims to provide a smooth flow of traffic on the road that connects the CBD section of Banjarmasin City. planning of signal timing coordination is expected to reduce delays at intersections and increase vehicle speed. The calculation of the performance of the existing intersection is carried out using the 2014 PKJI, and the Webster Method. Signal coordination requires the same cycle time for the four intersections obtained from the optimal intersection optimization results so that the cycle time is 116 seconds. Analysis of signal coordination by paying attention to the level of platoon spread and the distance between intersections and vehicle speed using offset and bandwidth theory so that the platoon as much as possible gets a sustainable green signal. The results showed an increase in intersection performance after being coordinated, namely a decrease in the value of the degree of saturation by an average of $10.81 \%$, a decrease in the average queue length of $7.61 \%$, and a decrease in the average delay of $2.69 \%$.
\end{abstract}

Keywords: Delay, Signal Coordination, Performance Improvement. 


\section{A. PENDAHULUAN}

Kota Banjarmasin merupakan ibukota Provinsi dari Provinsi Kalimantan Selatan, yang menjadikan Kota Banjarmasin menjadi pusat pemerintahan Provinsi. Pusat pemerintahan yang terletak pada pusat kota menjadikan banyak kendaraan yang melintas terutama di jalan arteri, sehingga menyebabkan tingginya volume lalu lintas pada ruas jalan di dalam kota.

Menurut UU No.38 Tahun 2004 Tentang Jalan, jalan adalah prasaran transportasi darat yang meliputi segala bagian jalan, termasuk bangunan pelengkap dan perlengkapannya yang di peruntukkan bagi lalu lintas, yang berada di permukaan tanah, di atas permukaan tanah, di bawah permukaan tanah, dan/atau air, serta di atas permukaan air, kecuali jalan kereta api, jalan lori, dan jalan kabel. berdasarkan Fungsinya jalan terbagi menjadi 3 (tiga) antara lain sebagai berikut:

a. Jalan Arteri adalah jalan yang melayani angkutan utama dengan ciri-ciri perjalanan jarak jauh, kecepatan rata-rata tinggi, dan jumlah jalan masuk dibatasi secara efisien.

b. Jalan Kolektor adalah yang melayani angkutan pengumpul/pembagi dengan ciri-ciri perjalanan jarak sedang, kecepatan rata-rata sedang, dan jumlah jalan masuk dibatasi.

c. Jalan local adalah jalan yang melayani angkutan setempat dengan ciri-ciri perjalanan jarak dekat, kecepatan rata-rata rendah, dan jumlah jalan masuk dibatasi.

Berdasarkan Kota Banjarmasin dalam angka 2019, Badan Pusat Statistik Kota Banjarmasin, memiliki keseluruhan panjang total jalan Kota Banjarmasin adalah 738,4 km , yang mana terdiri dari jalan nasional dengan panjang 17,55 km, jalan provinsi dengan panjang $7,78 \mathrm{~km}$, dan jalan kota dengan panjang $713,07 \mathrm{~km}$. jalan perkotaan yang menjadi akses utama dalam pergerakan umumnya terdapat banyak persimpangan yang jaraknya berdekatan, sehingga menambah waktu tempuh perjalanan akibat tundaan di persimpangan.

Persimpangan merupakan factor-faktor yang paling penting dalam menentukan kapasitas dan waktu perjalanan pada suatu jaringan jalan, khususnya didaerah-daerah perkotaan. Karena persimpangan harus dimanfaatkan bersama-sama oleh setiap orang yang ingin menggunakannya, maka persimpangan tersebut harus dirancang dengan hati-hati, dengan mempertimbangkan efesiensi, keselamatan, kecepatan, biara operasi, dan kapasitas. Prayoga (2017) menjelaskan bahwa Tingat pelayanan LOS (Level Of Service) merupakan ukuran kualitatif yang menerangkan kondisi operasional dalam arus lalu lintas dan penilaiannya oleh pemakai jalan pada umumnya dinyatakan dalam kecepatan, waktu tempuh, kebebasan pergerakan, intrupsi lalu lintas, kenyamanan dan keselamatan.Perencanaan simpang bertujuan untuk meminimalisir terjadinya kecelakaan karena konflik antar kendaraan, dan menghindari kebisingan dan polusi udara di persimpangan.

Pada Simpang Dewi tundaan rata-rata yaitu 38,56 detik/smp, dan derajat kejenuhan 0,67. Pada Simpang Duta Mall tundaan rata-rata yaitu 50,92 detik/smp, dan derajat kejenuhan 0,70. Pada Simpang Mak Haji tundaan rata-rata yaitu 26,15 detik/smp, dan derajat kejenuhan 0,69. Pada Simpang Terminal Antasari tundaan rata-rata yaitu 46,20 detik/smp, dan derajat kejenuhan 0,76. Dari data tersebut dapat dilihat bahwasanya tingginya tundaan rata-rata yang disebabkan pada keempat simpang yang jaraknya juga berdekatan.

Permasalah persimpangan lain yang disebabkan jarak antar simpang yang berdekatan adalah tundaan berlapis juga meningkatnya antrian pada simpang-simpang tersebut, dan pemborosan bahan bakar minyak (BBM) karena pembakaran yang tidak efektif, sehingga polusi udara meningkat pada persimpangan.

Ruas jalan yang menghubungkan bagian tengah Banjarmasin terdapat 4 (empat) simpang bersinyal yang jaraknya berdekatan dapat. Lokasi penelitian dilakukan di Simpang Dewi, Simpang Duta Mall, Simpang Mak Haji, dan Simpang Terminal Antasari. Kondisi tataguna lahan di sekitar persimpangan adalah pertokoan, perkantoran, hotel, sekolah, rumah ibadah, rumah sakit, dan mall. 
Jarak antar simpang dan tingginya arus lalu lintas pada jam puncak menimbulkan banyak permasalahan seperti yang dijelaskan diatas. Melihat kondisi permasalahan tersebut sehingga dipertimbangkan untuk dilakukannya penelitian yang berjudul "Koordinasi 4 (Empat) Simpang Bersinyal Untuk Kelancaran Arus Lalu Lintas Di Kota Banjarmasin".

\section{B. METODE}

Perhitungan kinerja eksisting persimpangan dilakukan dengan menggunakan PKJI 2014, dan Metode Webster. Untuk mempermudah dalam pemahaman proses-proses yang dilakukan dalam pengerjaan penelitian ini, maka perlu dibuat suatu alur penelitian, yang mana penelitian itu sendiri berarti sebuah pemikiran yang sistematis mengenai berbagai jenis masalah.pada alur penelitian ini akan dijelaskan proses-proses penelitian termasuk masukan sampai keluaran yang di harapakan oleh penulis. Pengumpulan data adalah langkah pencarian data yang akan digunakan untuk penelitian. Adapun data terbagi menjadi 2(dua) yaitu data sekunder berupa data yang diperoleh dari instansi pemerintah. Data tersebut sangat diperlukan dan berkaitan dengan penelitian yang dibahas dan Data primer merupakan data yang diperoleh langsung dari pengamatan di lapangan.

\section{HASIL DAN PEMBAHASAN}

\section{Validasi Perhitungan PKJI 2014}

Perhitungan PKJI 2014 digunakan untuk menghitung kinerja persimpangan berupa derajat kejenuhan, panjang antrian, dan tundaan di persimpangan. Perhitungan ini perlu diuji validitasnya agar meyakinkan bahwasanya hasil perhitungan sudah mendekati realita di lapangan. Sensitivitas hasil perhitungan dengan PKJI 2014 dapat dilihat dengan membandingkan panjang antrian hasil perhitungan dengan hasil survei panjang antrian. Dengan menggunakan analisis Chi-Kuadrat maka dapat disimpulkan perhitungan tersebut akurat atau tidak. Berikut adalah perbandingan panjang antrian dengan perhitungan PKJI 2014 dan perhitungan survei dapat dilihat pada Tabel 1 dibawah ini:

Tabel 1 Vaidasi Hasil Perhitungan PKJI 2014

\begin{tabular}{|c|c|c|c|c|c|}
\hline \multirow{2}{*}{ No } & \multirow{2}{*}{ Simpang } & \multirow{2}{*}{ Pendekat } & \multicolumn{2}{|c|}{ Panjang Antrian (m) } & \multirow{2}{*}{$\begin{array}{c}\text { Chi Kuadrat } \\
\left(X^{2}\right)\end{array}$} \\
\hline & & & Survei & Perhitungan & \\
\hline \multirow{3}{*}{1} & \multirow{3}{*}{ Simpang Dewi } & Selatan & 22.14 & 20.81 & 0.08 \\
\hline & & Timur & 48.21 & 54.48 & 0.815 \\
\hline & & Barat & - & - & - \\
\hline \multirow{3}{*}{2} & \multirow{3}{*}{$\begin{array}{c}\text { Simpang Duta } \\
\text { Mall }\end{array}$} & Utara & 19.28 & 24.56 & 1.446 \\
\hline & & Timur & 23.03 & 21.77 & 0.069 \\
\hline & & Barat & 62.18 & 60.37 & 0.053 \\
\hline \multirow{3}{*}{3} & \multirow{3}{*}{ Simpang Mak Haji } & Utara & - & - & - \\
\hline & & Selatan & 94.27 & 92.62 & 0.029 \\
\hline & & Barat & 103.93 & 102.57 & 0.018 \\
\hline \multirow{3}{*}{4} & \multirow{3}{*}{$\begin{array}{c}\text { Simpang Terminal } \\
\text { Antasari }\end{array}$} & Utara & 32.23 & 30.73 & 0.07 \\
\hline & & Selatan & 29 & 24.24 & 0.781 \\
\hline & & Timur & 32.77 & 22.12 & 3.461 \\
\hline
\end{tabular}




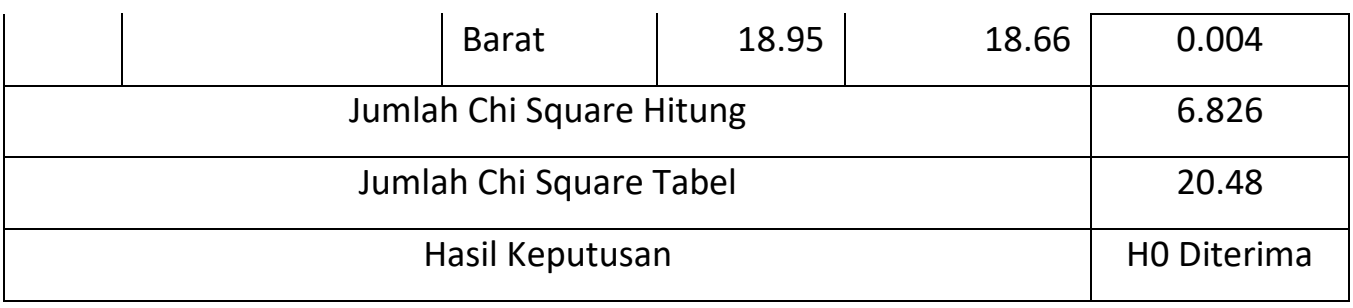

Sumber: Hasil Analisis

Berdasarkan hasil perhitungan pada tabel diatas, dapat disimpulkan bahwa H0 diterima karena $\mathrm{x}^{2}$ hitung < 20.48. Maksud dari H0 diterima ini menjelaskan bahwasanya model yang dibuat dapat diterapkan untuk rencana koordinasi keempat simpang.

\section{Analisa Koordinasi Simpang}

Koordinasi simpang bertujuan untuk meminimalkan tundaan perjalanan yang terjadi setiap melewati persimpangan. Rencana koordinasi simpang harus memperhatikan hal-hal sebagai berikut:

a) Tingkat Penyebaran Pleton

Panjang antrian pada persimpangan disebut pleton, dimana kumpulan kendaraan akan beriringan dalam melewati persimpangan. Jarak antar simpang menentukan hasil dari perhitungan tingkat penyebaran pleton. Hasil perhitungan membuktikan bahwa nilai couple index untuk masing-masing simpang diatas 0,5 sehingga simpang layak untuk direncanakan koordinasi sinyal. Jarak antar simpang mempengaruhi tingkat penyebaran pleton, dimana semakin panjang jarak simpang maka kemungkinan penyebaran semakin besar sehingga mengurangi efektivitas koordinasi sinyal. Berdasarkan pengukuran, jarak simpang Duta Mall menuju simpang Mak Haji adalah $0,150 \mathrm{Km}<0,402 \mathrm{Km}$ sehingga persentase kendaraan yang tetap dalam pleton yaitu $91 \%$. Sedangkan jarak simpang lainnya adalah $0,402 \mathrm{Km}<$ Jarak Simpang $<0,805 \mathrm{Km}$ sehingga persentase kendaraan yang tetap dalam pleton yaitu $85 \%$.

b) Perhitungan Waktu Offset

Waktu offset dihitung berdasarkan jarak antar simpang yaitu dengan membagi jarak dengan kecepatan rata-rata ruas penghung antar simpang. Hasil perhitungan digunakan untuk menentukan mulai sinyal hijau di masing-masing persimpangan. Berikut adalah perhitungan waktu offset untuk perjalanan dari barat menuju timur dan sebaliknya dapat dilihat pada Tabel 2 dan Tabel 3 sebagai berikut:

Tabel 2 Perhitungan Waktu Offset Berdasarkan Kecepatan Pleton barat ke Timur

\begin{tabular}{|l|l|l|l|l|}
\hline Simpang Asal & $\begin{array}{l}\text { Simpang } \\
\text { Tujuan }\end{array}$ & $\begin{array}{l}\text { Jarak } \\
(\mathrm{km})\end{array}$ & $\begin{array}{l}\text { Kecepatan Rata-Rata Pleton } \\
(\mathrm{Km})\end{array}$ & $\begin{array}{l}\text { Waktu Offset } \\
(\text { detik })\end{array}$ \\
\hline Terminal Antasari & Dewi & 0,550 & 35,00 & 56 \\
\hline Dewi & Duta Mall & 0,600 & 45,00 & 48 \\
\hline Duta Mall & Mak Haji & 0,240 & 40,00 & 21 \\
\hline
\end{tabular}

Sumber: Hasil Analisis

Tabel 3 Perhitungan Waktu Offset Berdasarkan Kecepatan Pleton Timur ke Barat lalu ke Utara 


\begin{tabular}{|l|l|l|l|l|}
\hline Simpang Asal & $\begin{array}{l}\text { Simpang } \\
\text { Tujuan }\end{array}$ & $\begin{array}{l}\text { Jarak } \\
(\mathrm{km})\end{array}$ & $\begin{array}{l}\text { Kecepatan } \\
\text { Rata-Rata } \\
\text { Pleton }(\mathrm{Km})\end{array}$ & $\begin{array}{l}\text { Waktu } \\
\text { Offset } \\
(\text { detik })\end{array}$ \\
\hline Mak Haji & Duta Mall & 0,240 & 35,00 & 24 \\
\hline Duta Mall & Dewi & 0,600 & 40,00 & 54 \\
\hline Dewi & $\begin{array}{l}\text { Terminal } \\
\text { Antasari }\end{array}$ & 0,550 & 45,00 & 44 \\
\hline
\end{tabular}

Sumber: Hasil Analisis

c) Penentuan Waktu Siklus yang Sama

Koordinasi sinyal harus memiliki waktu siklus yang sama, dimana waktu siklus optimum terbaik dari optimasi keempat simpang. Optimasi waktu sinyal bertujuan untuk mendapatkan waktu siklus yang optimal, sehingga panjang antrian dan lama tundaan berkurang. Analisis arus lalu lintas bertujuan untuk menentukan arus terbesar pada masingmasing kaki persimpangan dan menghitung besar arus belok kanan, sehingga waktu hijau terbesar didapatkan oleh arus yang lalu lintas tertinggi pada persimpangan.

Dari perhitungan idapatkan waktu siklus yang optimal untuk simpang Terminal Antasari adalah 62 detik. Selanjutnya ditentukan waktu siklus terbaik yang dapat diterapkan untuk koordinasi empat simpang. Waktu siklus yang terpilih adalah 116 detik, dimana waktu tersebut memberikan kinerja yang lebih optimal.

d) Diagram Koordinasi Simpang

Diagram Koordinasi menggambarkan aliran pleton dari satu titik ke titik yang lain dan memberikan hubungan antara kedua titik. Berdasarkan hasil penggambaran menunjukkan aliran pleton yang terus mendapatkan waktu hijau baik dari selatan menuju utara atau sebaliknya. Waktu offset berdasarkan jarak simpang dan kecepatan kendaraan yaitu dapat dilihat pada tabel V.38 dan tabel V.39, selanjutnya bandwith merupakan panjang lintasan yang mendapatkan sinyal hijau selama koordinasi sinyal. Bandwith ditentukan berdasarkan panjang antrian pada awal dimulainya koordinasi sinyal, untuk bandwith arus dari selatan menuju utara sebesar 25 detik dan bandwith utara menuju selatan sebesar 21 detik. Selanjutnya bandwith merupakan panjang lintasan yang mendapatkan sinyal hijau selama koordinasi sinyal. Bandwith ditentukan berdasarkan panjang antrian pada awal dimulainya koordinasi sinyal, untuk bandwith arus dari selatan menuju utara sebesar 25 detik dan bandwith utara menuju selatan sebesar 21 detik.

\section{Perbandingan Kinerja Persimpangan Terkoordinasi}

Koordinasi sinyal diterapkan untuk mendapatkan kinerja persimpangan dan jaringan yang lebih optimal. Berikut adalah perbandingan kinerja persimpangan antara kondisi eksisting dan setelah diterapkan koordinasi simpang dapat dilihat pada Tabel 4 sebagai berikut:

Tabel 4 Perbandingan Kinerja Persimpangan Eksisting dan Terkoordinasi

\begin{tabular}{|c|c|c|c|c|c|c|c|}
\hline \multirow{2}{*}{$\begin{array}{l}\text { Nama } \\
\text { Simpang }\end{array}$} & \multirow{2}{*}{$\begin{array}{l}\text { Pendeka } \\
\mathrm{t}\end{array}$} & \multicolumn{2}{|c|}{ Derajat Kejenuhan } & \multicolumn{2}{|c|}{ Panjang Antrian } & \multicolumn{2}{|l|}{ Tundaan } \\
\hline & & $\begin{array}{c}\text { Eksistin } \\
\mathrm{g}\end{array}$ & $\begin{array}{c}\text { Terkoordinas } \\
\text { i }\end{array}$ & $\begin{array}{c}\text { Eksistin } \\
\mathrm{g}\end{array}$ & $\begin{array}{c}\text { Terkoordinas } \\
\text { i }\end{array}$ & $\begin{array}{c}\text { Eksistin } \\
\mathrm{g}\end{array}$ & $\begin{array}{c}\text { Terkoordinas } \\
\text { i }\end{array}$ \\
\hline \multirow{4}{*}{$\begin{array}{l}\text { Simpang } \\
\text { Termina } \\
1 \\
\text { Antasari }\end{array}$} & Utara & 0,52 & 0,44 & 32,23 & 25,50 & 56,35 & 55,03 \\
\hline & Selatan & 0,68 & 0,55 & 29,00 & 20,59 & 62,20 & 57,03 \\
\hline & Barat & 0,76 & 0,44 & 32,77 & 18,97 & 69,49 & 53,26 \\
\hline & Timur & 0,37 & 0,37 & 18,95 & 16,25 & 53,98 & 53,91 \\
\hline
\end{tabular}




\begin{tabular}{|c|c|c|c|c|c|c|c|}
\hline \multirow{3}{*}{$\begin{array}{l}\text { Simpang } \\
\text { Dewi }\end{array}$} & Selatan & 0,48 & 0,36 & 22,14 & 20,81 & 35,25 & 34,42 \\
\hline & Timur & 0,67 & 0,86 & 48,21 & 54,38 & 37,31 & 36,39 \\
\hline & Barat & & & & & & \\
\hline \multirow{3}{*}{$\begin{array}{l}\text { Simpang } \\
\text { Duta } \\
\text { Mall }\end{array}$} & Utara & 0,62 & 0,83 & 19,28 & 24,56 & 54,04 & 65,31 \\
\hline & Timur & 0,61 & 0,46 & 23,03 & 21,77 & 55,05 & 52,72 \\
\hline & Barat & 0,70 & 0,56 & 62,18 & 60,37 & 54,26 & 52,89 \\
\hline \multirow{3}{*}{$\begin{array}{l}\text { Simpang } \\
\text { Mak } \\
\text { Haji }\end{array}$} & Utara & & & & & & \\
\hline & Selatan & 0,60 & 0,46 & 94,27 & 92,62 & 42,38 & 41,29 \\
\hline & Barat & 0,69 & 0,64 & 103,93 & 102,57 & 45,43 & 44,43 \\
\hline
\end{tabular}

Sumber: Hasil Analisis

Tabel diatas menjelaskan perbandingan kinerja masing-masing simpang dari beberapa indikator yaitu derajat kejenuhan, panjang antrian, dan tundaan. tabel hasil persentase perbandingan dapat dilihat pada Tabel 5 sebagai berikut.

Tabel 5 Persentase Perbandingan Kinerja Simpang

\begin{tabular}{|c|c|c|c|c|}
\hline \multirow{2}{*}{ Nama Simpang } & \multirow{2}{*}{ Pendekat } & $\begin{array}{l}\text { Derajat } \\
\text { Kejenuhan }\end{array}$ & $\begin{array}{l}\text { Panjang } \\
\text { Antrian }\end{array}$ & Tundaan \\
\hline & & $\begin{array}{l}\text { Perbandingan } \\
(\%)\end{array}$ & $\begin{array}{l}\text { Perbandingan } \\
(\%)\end{array}$ & $\begin{array}{l}\text { Perbandingan } \\
(\%)\end{array}$ \\
\hline \multirow{4}{*}{$\begin{array}{l}\text { Simpang } \\
\text { Terminal } \\
\text { Antasari }\end{array}$} & Utara & -15.38 & -21.13 & -2.34 \\
\hline & Selatan & -19.12 & -29.00 & -8.31 \\
\hline & Barat & -42.11 & -42.11 & -23.36 \\
\hline & Timur & 0 & -14.25 & -0.13 \\
\hline \multirow{3}{*}{ Simpang Dewi } & Selatan & -25.00 & -6.01 & -2.35 \\
\hline & Timur & 28.36 & 12.80 & -2.47 \\
\hline & Barat & & & \\
\hline \multirow{3}{*}{$\begin{array}{c}\text { Simpang Duta } \\
\text { Mall }\end{array}$} & Utara & 33.87 & 27.39 & 20.85 \\
\hline & Timur & -24.59 & -5.47 & -4.23 \\
\hline & Barat & -20.00 & -2.91 & -2.52 \\
\hline \multirow{3}{*}{$\begin{array}{c}\text { Simpang Mak } \\
\text { Haji }\end{array}$} & Utara & & & \\
\hline & Selatan & -23.33 & -1.75 & -2.57 \\
\hline & Barat & -11.59 & -1.31 & -2.20 \\
\hline \multicolumn{2}{|c|}{ Rata-Rata } & -10.81 & -7.61 & -2.69 \\
\hline
\end{tabular}

Sumber: Hasil Analisis

Tabel diatas merupakan persantase perbandingan kinerja persimpangan sebelum dan rencana koordinasi sinyal antar simpang. Hasil perbandingan negatif (-) menunjukkan adanya penurunan nilai pada masing-masing indikator yang berarti kinerja menjadi lebih baik. Penurunan nilai derajat kejenuhan setiap pendekat pada keempat simpang rata-rata sebesar $10,81 \%$, penurunan panjang antrian setiap pendekat rata-rata sebesar $7,61 \%$, dan penuruan pada tundaan setiap pendekat keempat simpang rata-rata sebesar $2,69 \%$. 


\section{KESIMPULAN}

Kondisi eksisting pada keempat simpang bersinyal yang dikaji belum terkoordinasi diketahui dari waktu siklus yang berbeda pada masing-masing simpang. Jarak antar simpang yang berdekatan menyebabkan tundaan setiap melewati keempat simpang dan menambah waktu tempuh perjalanan. Waktu siklus optimal yang digunakan untuk koordinasi keempat simpang adalah 116 detik, didapatkan dari hasil optimasi keempat simpang yang menunjukkan kinerja persimpangan yang paling optimal. Meninjau kinerja antara sebelum dan setelah dilakukannya koordinasi simpang adalah sebagai berikut Peningkatan kinerja persimpangan yaitu dengan penurunan nilai derajat kejenuhan setiap pendekat pada empat simpang rata-rata sebesar $10,81 \%$. Penurunan tertinggi yaitu pada pendekat barat simpang terminal antasari sebesar 42,11\%; Panjang antrian pada setiap pendekat berkurang setelah diterapkan koordinasi sinyal rata-rata sebesar $7,61 \%$. Penurunan tertinggi yaitu pada pendekat barat simpang terminal antasari sebesar $42,11 \%$; Peningkatan kinerja persimpangan yaitu pada penurunan nilai tundaan pada setiap pendekat rata-rata sebesar $2,69 \%$.

\section{DAFTAR PUSTAKA}

Abubakar, Iskandar. 1996. Menuju Lalu Lintas dan Angkutan Jalan Yang Tertib. Edisi yang disempurnakan. Jakarta: Direktorat Jenderal Perhubungan Darat.

Anisari, Rizky. 2017. Koordinasi Simpang Empat Bersinyal Jalan S.Parman-Belitung Dengan S.Parman-Tarakan Kota Banjarmasin. Jurnal Gradasi Teknik Sipil. 1(1). 1-8.

Auladi, Muhammad Hanif. 2019. Koordinasi Lima Simpang Bersinyal Untuk Kelancaran Arus Lalu Lintas di Kota Purwokerto. Skripsi Program DIV Transportasi Darat. Bekasi: STTD.

Cahyaningrum, Fitria Purnayanti. 2013. Koordinasi Simpang Bersinyal (Studi Kasus: Simpang Kentungan-Simpang Monjali, Yogyakarta) Skripsi S1 Teknik Sipil Universitas Gadjah Mada. Yogyakarta: Universitas Gadjah Mada.

Dewi, Monica Wahyu Candra. 2018. Perencanaan Koordinasi Simpang Bersinyal Pada Jalan Sujarwo Condronegoro Di Kabupaten Manokwari. Skripsi Program DIV Transportasi Darat. Bekasi: STTD.

Direktorat Bina Marga. 2014. Pedoman Kapasitas Jalan Indonesia (PKJI) 2014. Jakarta: Direktorat Bina Marga.

Fadhillah, Rizky Wahyu dan Ahmad, Ramadan Ridlo. 2016. Kajian Koordinasi Simpang Jalan Patimura Dengan Simpang Jalan Panglima Sudirman Kota Malang. Skripsi S1 Teknik Sipil Universitas Brawijaya. Malang: Universitas Brawijaya.

Herdiyanti, Septiana Nurvita. 2013. Optimalisasi dan Koordinasi Sinyal Antar Simpang Pada Lima Simpang Bersinyal dan Satu Simpang Prioritas di Kota Kendari. Skripsi Program DIV Transportasi Darat. Bekasi: STTD.

Ikhwan, Muhammad, Legowo, J. Slamet. 2014. Analisa Dan Koordinasi Sinyal Antar Simpang Sumber Dan Simpang Pom Bensin Manahan. Jurnal Matriks Teknik Sipil. 351359.

Jati, Joko Umboro. 2005. Pengkoordinasian Lampu Lalu Lintas Guna Peningkatan Kinerja Jalan (Studi Kasus pada Jalan Brigjend.Sudiarto, Kota Semarang). Skripsi Program DIV Transportasi Darat. Bekasi: STTD.

Kelompok PKL Kota Banjarmasin. 2019. Pola Umum Transportasi Darat Kota Banjarmasin. Bekasi, Sekolah Tinggi Transportasi Darat.

Khisty, J., 2003, Dasar-Dasar Rekayasa Transportasi Jilid 1 Edisi Ketiga. Jakarta, Erlangga. Kirono, Joko Candra, Puspasari, Nirwana, Handayani, Noviyanthi. 2018. Analisis Koordinasi Simpang Antar Simpang (Studi Kasus Jalan Rajawali - Tinggang dan Jalan Rajawali - Garuda). Media Ilmiah Teknik Sipil., hal. 109-123. 
Kuncoro, Wahyu. 2010. Koordinasi Lampu Lalu Lintas Persimpangan (Studi Kasus Ruas Jalan Veteran - Pemuda di Kabupaten Klaten). Skripsi Program DIV Transportasi Darat. Bekasi: STTD.

Kurnia, Indra, Silitonga, P. Sultan. 2016. Analisis Simpang Terkoordinasi Di Kota Palangkaraya. Jurnal Proyeksi Teknik Sipil. 2(2). 215-218.

Mulizar, Anggraini, Renni, dan Isya, Muhammad. 2014. Perencanaan Koordinasi Simpang Bersinyal di Kota Lhokseumawe. Jurnal Teknik Sipil. 1(3). 46-57

Munawar, Ahmad. 2004. Dasar-Dasar Teknik Transportasi. Yogyakarta: Beta Offset.

Munawar, Ahmad. 2006. Manajemen Lalu Lintas Perkotaan, Yogyakarta

Papacostas, C.S and Prevedouros, P.D. 2005. Transportation Engineering and Planning. Singapore: Prantice Hall Inc.

Peraturan Menteri Nomor 96 tentang Pedoman dan Pelaksanaan Manajemen dan Rekayasa Lalu Lintas. Jakarta: Departemen Perhubungan.

Peraturan Pemerintah Nomor 32 tentang Manajemen dan Rekayasa Lalu Lintas. Jakarta: Departemen Perhubungan.

Prayoga. 2017. Analisis Koordinasi Sinyal Antar Simpang Pada Ruas Jalan Z.A Pagar Alam. Skripsi S1 Teknik Sipil Universitas Lampung. Lampung: Univesitas Lampung.

Sigit, Nafis Ardian. 2017. Perbandingan Kinerja Simpang Bersinyal Terkoordinasi Antara Transyt 14 dan PTV VISSIM 9. Skripsi Program DIV Transportasi Darat. Bekasi: STTD.

Suryani, Deci. 2016. Koordinasi Lima Simpang Bersinyal di Kota Palembang. Skripsi Program DIV Transportasi Darat. Bekasi: STTD.

Tamin, O.Z., 2010, Perencanaan, Permodelan dan Rekayasa Transportasi. Bandung: ITB.

Taylor, M. dan Young, W. 1996. Understanding Traffic System. Sydeny: Avebury Technical. Undang-Undang Nomor 22 Tahun 2009 tentang Lalu Lintas dan Angkutan Jalan. Jakarta: Departemen Perhubungan.

Zainuri, Muhammad Akbar. 2018. Koordinasi Sinyal Antar Simpang BPK Dan Simpang Badran Yogyakarta. Skripsi S1 Teknik Sipil Universitas Islam Indonesia. Yogyakarta: Universitas Islam Indonesia. 